\title{
PENGARUH KEPUASAN KERJA TERHADAP KINERJA KARYAWAN MELALUI KOMITMEN AFEKTIF PADA PT CIPTA NIRMALA
}

\author{
Lia Widya Ningsih \\ Universitas Negeri Surabaya \\ lianigsih@mhs.unesa.ac.id
}

Abstract

\begin{abstract}
This study aims to explain and identify job satisfaction, affective commitment and employee performance at PT Cipta Nirmala. The position of affective commitment in mediating job satisfaction on PT Cipta Nirmala's employee performance was tested and analyzed in this study. The population is all permanent employees in the PT Cipta Nirmala office section, amounting to 50 employees. The analysis technique uses SEM analysis by Smart PLS3. This research gives the result that positively and significantly, job satisfaction affects employee performance. Positively and significantly, job satisfaction is affected by affective commitment. There is no mediating affective commitment to job satisfaction in influencing employee performance.
\end{abstract}

Keywords: affective commitment; employee performance; job satisfaction.

\section{PENDAHULUAN}

Digitalisasi di masa sekarang ini menjadi sebuah hal yang umum terjadi pada semua lapisan masyarakat. Rangkaian teknologi digital saat ini telah banyak digunakan untuk membantu berbagai aktivitas menusia. Perlu adanya peningkatan skills dan work habbits pegawai, penyisihan jabatan pada tingkat rendah dan level manajerial, berkurangnya hirarki, kerjasama atau kolaborasi menjadi orientasi utama akan menjadi respon perubahan teknologi baru yang berdampak pada organisasi (Mello, 2015).

Kemudahan dalam mencapai tujuan organisasi dan menghadapi masalah dapat diperoleh ketika sumber daya manusia berperan aktif dan memberikan dukungan penuh dalam organisasi. Peran dan dukungan tersebut akan timbul ketika seseorang dalam organisasi mempunyai rasa puas dalam bekerja. Seseorang yang memiliki positive thinking pada pekerjaannya akan memiliki kepuasan dalam bekerja. Sementara itu, jika mereka hanya memiliki negative thinking pada pekerjaannya maka tidak akan ada kepuasan mengenai pekerjaannya (Robbins, 2012).

Ketidakpuasan kerja bagi karyawan mungkin tidak akan membuat mereka berhenti dari pekerjaannya, tetapi perasaan ketidakpuasan tersebut akan memberikan dampak bagi karyawan tentang mutu dari kinerja dan layanan yang mereka berikan. Hal ini berarti karyawan yang tidak puas tersebut memiliki kecenderungan akan menunjukkan permusuhan terhadap karyawan lain yang ada pada lingkungan kerja (Squires et al., 2015).

Kepuasan kerja akan ada ketika individu bersikap positif dalam hal yang berhubungan dengan pekerjaannya (Duha, 2016). Kepuasan kerja merupakan tindakan seseorang terhadap pekerjaannya, sisa dari perolehan upah yang diterima dengan perolehan upah yang mereka yakini harus diterima (Sani, 2013). Kepuasan kerja dapat terbentuk dari komitmen organisasi pada karyawan. Perasaan suka pada organisasi serta memaksimalkan usahanya untuk pencapaian tujuan serta kepentingan organisasi dapat didefinisikan sebagai komitmen organisasi (Suparyadi, 2015). Seseorang ketika memiliki kepuasan pada pekerjaannya akan termotivasi untuk menetap pada pekerjaannya dan memilih bertahan akan segala situasinya (Rini et al., (2013)

Tiga dimensi yang dimiliki komitmen organisasi (organizational commitment) yaitu affective commitment, continuance commitment, dan normative commitment (Robbins \& Timothy (2015). Diantara tiga dari dimensi komitmen organisasi, affective commitment dinilai lebih tinggi daripada dua dimensi yang lainnya, serta normative commitment dinilai lebih tinggi daripada continuance 
commitment (Boon et al., 2006). Komitmen afektif merupakan ketertarikan emosional individu dengan organisasi (Dinc \& Plakalovic, 2016). Kontribusi yang bermanfaat pada organisasi akan menjadi motivasi dan keinginan karyawan ketika memiliki affective commitment yang tinggi dan akan berbanding terbalik dengan karyawan dengan affective commitment yang lebih rendah (Ratnasari \& Hartati, 2019). Penelitian dari Dinc \& Plakalovic (2016), secara signifikan komitmen afektif memberikan pengaruh pada kinerja karyawan.

Pembahasan penelitian ini berfokus pada karyawan bagian kantor PT Cipta Nirmala. PT Cipta Nirmala adalah sebuah bidang usaha pada bidang pelayanan kesehatan dan sarana penunjang yang bertempat di jalan R. A. Kartini No 280, Sukorame Gresik. Bidang pelayanan kesehatan dan sarana penunjang yang di bawahi PT Cipta Nirmala yaitu Rumah Sakit Semen Gresik, 3 unit Apotek di Gresik, sebuah Apotek di Tuban serta Balai Pengobatan dan Rumah Bersalin di Tuban. Karyawan pada bagian kantor PT Cipta Nirmala dipilih sebagai objek penelitian karena pada bagian kantor PT Cipta Nirmala sedang berlangsung peralihan dari penggunaan pengolahan data menggunakan software yang lama menuju software yang lebih modern.

Hasil yang ditunjukkan dari survei secara internal oleh PT Cipta Nirmala mengenai kepuasan kerja karyawannya menunjukkan bahwa kepuasan karyawan masih tergolong sedang. Hal tersebut ditunjukkan dengan adanya data survei kepuasan kerja karyawan pada tiga tahun terakhir yang menyatakan bahwa tingkat kepuasan kerja karyawan yang berkisar antara 60-65 persen. Selain itu, berdasarkan wawancara dengan beberapa orang di PT Cipta Nirmala menunjukkan bahwa ada yang membuat mereka kurang merasa puas akan pekerjaan mereka. Fenomena lain yang ada pada PT Cipta Nirmala yaitu komitmen organisasi yang tinggi. Hal tersebut ditunjukkan dari data karyawan PT Cipta Nirmala yang telah bekerja $>10$ tahun lebih banyak daripada yang $<10$ tahun. Hal tersebut dapat menunjukkan tingginya komitmen organisasi pada dimensi komitmen afektif. Sehingga pada PT Cipta Nirmala, karyawan mampu bertahan lama pada perusahaan. Wawancara yang dihasilkan dari beberapa karyawan menyatakan bahwa mereka berkecenderungan untuk ingin bertahan pada perusahaan karena sudah merasa nyaman dan menyatu menjadi bagian dari perusahaan.

Fenomena menarik lain yang terdapat di sini adalah meskipun tingkat komitmen organisasi karyawan PT Cipta Nirmala tinggi, namun tingkat kinerja karyawan tidak semuanya mengalami peningkatan, ada sebagian karyawan yang kinerjanya menurun. Hal tersebut disampaikan melalui wawancara dengan Pak Sugiyanto selaku karyawan bagian SDM yang menyatakan bahwa kinerja karyawan selama tiga tahun terakhir secara keseluruhan cukup baik. Namun, beberapa karyawan ada yang kadang terlambat dalam penyelesaian kinerjanya. Sehingga analisis pada penelitian ini dilakukan dengan tujuan untuk mengetahui bagaimana kedudukan komitmen afektif dalam memediasi pengaruh kepuasan kerja pada kinerja karyawan pada PT Cipta Nirmala.

\section{KAJIAN PUSTAKA DAN PENGEMBANGAN HIPOTESIS}

\section{Kepuasan Kerja}

Kepuasan kerja diidentifikasi sebagai suatu perspektif individu yang ada kaitannya dengan pemikiran positif maupun negatif akan pekerjaan yang dimiliki (Asepta, 2017). Hal tersebut berbanding lurus dengan Mahesa (2018) yang mengatakan bahwa kepuasan kerja adalah suatu respon emosi yang muncul dari evaluasi kerja karyawan atau pengalaman kerja yang bersifat positif. Sedangkan menurut Maslicah (2017) kepuasan kerja merupakan rasa menyenangkan yang timbul dari sikap emosional seseorang dan memengaruhi individu agar lebih mencintai pekerjaan yang dikerjakan. Hal tersebut didapatkan melalui kepatuhan, kejujuran saat bekerja dan kinerja saat bekerja. Dengan demikian, perusahaan perlu mengevaluasi kepuasan kerja dari setiap karwayan, karyawan yang merasa tidask puas akan pekerjaan yang dikerjakan akan menimbulkan perasaan untuk meninggalkan pekerjaannya, melakukan komplain, tidak memiliki sikap penurut pada perusahaan, tidak bertanggung jawab terhadap pekerjaannya, dan lain sebagainya (Nurendra \& Saraswati, 2016) 
Lia Widya Ningsih. Pengaruh Kepuasan Kerja terhadap Kinerja Karyawan melalui Komitmen Afektif pada PT Cipta Nirmala

Kepuasan kerja merupakan sikap seorang terhadap pekerjaannya, sisa antara total upah yang diterima dengan total upah yang mereka percaya harus diterima (Kerisna \& Suana, 2017). Respon emosional atau secara afektif terhadap berbagai bidang pekerjaan serta sikap individu saat bekerja dapat disebut sebagai kepuasan kerja. Positive thinking dalam bekerja akan menimbulkan kepuasan kerja, sementara negative thinking tentang pekerjaan akan menimbulkan seseorang tidak puas akan pekerjannya (Kreitner \& Kinicki, 2014).

\section{Komitmen Afektif}

Komitmen afektif adalah bagian dari tiga dimensi yang dimiliki oleh komitmen organisasi (Robbins \& Timothy, 2015). Komitmen organisasi merupakan pemaksimalan seseorang dalam kepentingan sebuah organisasi dalam pencapaian tujuan yang berdasarkan perasaan suka pada organisasi (Suparyadi, 2015). Affective commitment, continuance commitment dan normative commitment merupakan tiga dimensi yang dimiliki organizational commitment (Robbins \& Timothy 2015). Affective commitment bernilai lebih tinggi dari pada normative commitment dan continuance commitment (Boon, Safa, \& Arumugam (2006).

Keterikatan seseorang secara emosional terhadap organisasinya dianggap Meyer \& Allen (1991) sebagai komitmen afektif (affective commitment). Pelekatan emosi pada identifikasi pegawai dengan ketersangkutan pegawai dalam perusahaan disebut sebagai komitmen afektif (Kreitner \& Kinicki 2014). Sebuah komitmen afektif dapat terbentuk ketika ada kesenangan tersendiri menjadi bagian perusahaan, percaya, dan nyaman pada organisasi serta bersedia melakukan sesuatu untuk kepentingan oerganisasi (George \& Jones, 2007). Sehingga seseorang akan berkeinginan terus bekerja pada sebuah perusahaan ketika mereka memiliki komitmen afektif yang kuat.

\section{Kinerja Karyawan}

Perilaku dan hasil dari kegiatan yang dilakukan karyawan atau fungsi pekerjaan yang dilakukan disebut sebagai kinerja karyawan (Amstrong \& Baron, 2005). Kinerja (prestasi kerja) adalah sebuah pencapaian yang dihasilkan dari seseorang yang telah menyelesaikan beban kewajiban yang diberikan berdasarkan kecakapan, pengalaman, kesungguhan dan waktu (Hasibuan, 2009). Kualitas dan kuantitas dari pencapaian yang diperoleh seorang pekerja pada saat pelaksanaan tugasnya disebut sebagai kinerja (Mangkunegara 2013). Evaluasi kinerja terbaik adalah ketika dilakukan atasan langsung karyawan (Robbins, 2001). Sedangkan menurut Simamora (2006) partisipasi karyawan pada organisasi selama priode waktu tertentu dapat dijadikan untuk penilaian kinerja.

H1: Kepuasan kerja berpengaruh positif dan signifikan terhadap kinerja karyawan pada Cipta Nirmala

\section{Pengaruh Kepuasan Kerja terhadap Kinerja Karyawan}

Individu yang memiliki sikap positif dalam hal yang terlibat dengan pekerjaannya disebut memiliki sebuah kepuasan kerja (Duha, 2016). Alternatif pekerjaan yang lain tidak akan diinginkan oleh karyawan yang merasa senang dan bahagia akan pekerjaannya. Sebaliknya, karyawan dengan rasa tidak puas pada pekerjaan yang dijalaninya cenderung berpemikiran tidak serius dan menginginkan pekerjaan alternatif yang lain. Ketidakpuasan kerja karyawan mungkin tidak membuat seorang karyawan berhenti dari pekerjaan mereka saat itu juga, namun hal tersebut akan berpengaruh terhadap diri mereka sendiri, rekan kerja, mutu kinerja, dan layanan yang akan mereka berikan. Sehingga, kepuasan kerja akan berpengaruh pada kinerja yang mereka lakukan (Squires et al., 2015).

Kinerja karyawan dipengaruhi oleh kepuasan kinerja telah diteliti pada 139 karyawan pada PT Telekomunikasi Indonesia oleh Novita et al., (2016), yang memberikan hasil kinerja karyawan secara signifikan positif dipengaruhi oleh kepuasan kerja. Sementara itu di seluruh Rumah Sakit Swasta untuk wilayah kota Denpasar Bali telah diteliti oleh Indrawati (2013) dengan sampel sejumlah 100 orang responden yang menyebutkan hasil yang sama yaitu kinerja karyawan secara signifikan positif dipengaruhi kepuasan kerja. 
Pembuktian mengenai positif dan signifikannya kepuasan kerja dalam memberikan pengaruhnya pada kinerja karyawan telah dibuktikan melalui berbagai penelitian terdahulu, diantaranya yaitu penelitian oleh Atmojo (2017), Armanu \& Mandayanti (2012), Dinc \& Plakalovic (2016), Inuwa (2016), Nurnaningsih \& Wahyono (2017), Roberts \& David (2020), Siengthai \& Pila-Ngarm (2016), Parven \& Awan (2018), Ezeanyim et al., (2019), Riyadi (2019) dan Perangin-Angin et al., (2020).

H2: Kepuasan kerja berpengaruh positif dan signifikan terhadap komitmen afektif pada PT Cipta Nirmala

\section{Pengaruh Komitmen Afektif terhadap Kinerja Karyawan}

Karyawan akan mengusahakan secara optimal untuk tercapainya tujuan perusahaan ketika memiliki komitmen afektif, sedangkan karyawan dengan komitmen kontinuan cenderung melakukan kewajibannya untuk terhindar dari berbagai kerugian seperti financial dan lainnya hingga cenderung tidak maksimal pada pekerjaannya (Hanifah, 2016). Dorongan dan harapan untuk berkontribusi pada karyawan secara berarti terhadap organisasi adalah ketika mereka mempunyai komitmen afektif yang tinggi dan akan berbanding terbalik dengan karyawan yang cenderung lebih rendah komitmen afektifnya (Ratnasari \& Hartati, 2019).

Pengaruh komitmen afektif terhadap kinerja dibuktikan melalui penelitian Armanu \& Mandayanti (2012) pada 89 orang pegawai Dinas Tata Kota Mataram baik yang berstatus sebagai PNS maupun honorer, yang mengemukakan bahwa kepuasan kerja memengaruhi kinerja karyawan. Sebuah penelitian pada 343 staf non akademik dari tiga Lembaga tersier di Ekiti State oleh Israel et al., (2015) mengutarakan hal yang sama yaitu secara signifikan positif kinerja karyawan dipengaruhi komitmen afektif. Komitmen afektif secara signifikan positif memengaruhi kinerja karyawan telah diteliti sebelumnya, diantaranya oleh Manuel \& Rahyuda (2015), Dinc \& Plakalovic (2016), Israel et al., (2015) dan Mustafa et al., (2016).

H3: Komitmen afektif berpengaruh positif dan signifikan terhadap kinerja karyawan pada PT Cipta Nirmala

\section{Pengaruh Kepuasan Kerja terhadap Komitmen Afektif}

Individu dengan kepuasan kerja yang dimiliki akan menjadi salah satu alasan meningkatnya komitmen organisasi, kepuasan seorang individu terhadap pekerjaannya akan membentuk adanya komitmen terhadap perusahaannya begitupun sebaliknya. Jika kepuasan tersebut tidak ada, maka kesulitan akan didapat untuk berkomitmen pada perusahaannya (Robbins, 2012). Komitmen afektif dapat dianggap sebagai salah satu dari dimensi komitmen organisasi yang berhubungan kuat pada kepuasan kerja (Meyer et al., 2002). Rini et al. (2013) menyatakan karyawan akan termotivasi bertahan dan menetap dalam segala situasi yang akan diterimanya adalah ketika mereka merasakan kepuasan dalam melakukan pekerjaannya selama ini.

Menurut penelitian Dinc \& Plakalovic (2016) terdapat pengaruh secara signifikan positif antara komitmen afektif terhadap kinerja karyawan yang dilakukan pada 152 karyawan bank umum dan swasta di Sarajevo ibukota FBiH. Penelitian yang dilakukan oleh Memari et al. (2013), Nurbiyati \& Wibisono (2014), Dinc \& Plakalovic (2016) dan Armanu \& Mandayanti (2012) merupakan penelitian yang telah membuktikan hasil yang sama.

H4: Komitmen afektif memediasi pengaruh kepuasan kerja terhadap kinerja karyawan pada PT Cipta Nirmala.

\section{METODE PENELITIAN}

Penelitian asosiatif melalui pendekatan kuantitatif merupakan jenis penelitian dalam penelitian ini. Penggunaan variabel pada penelitian ini ada tiga variabel yang terdiri dari dependent variable, independent variable dan intervening variable. Kepuasan kerja $(\mathrm{X})$ merupakan dependent variable 
Lia Widya Ningsih. Pengaruh Kepuasan Kerja terhadap Kinerja Karyawan melalui Komitmen Afektif pada PT Cipta Nirmala

pada penelitian ini dengan lima indikator yaitu profesi itu sendiri, upah, peluang mendapatkan promosi, pengawasan, dan teman dalam bekerja yang mengacu pada Luthans (2006). Kinerja karyawan (Y) merupakan independent variable dalam penelitian ini dengan tiga indikator yaitu rasa senang berada pada organisasi, ikatan secara emosional pada perusahaan, dan menjadi anggota pada perusahaan yang mengacu Dharma (2003). Komitmen afektif $(Z)$ dalam penelitian ini merupakan variabel intervening dengan tiga indikator yaitu kualitas, kuantitas, dan ketepatan yang mengacu Meyer \& Allen (1991).

Seluruh karyawan PT Cipta Nirmala yang bekerja pada bagian kantor yang berjumlah 50 orang digunakan sebagai populasi sekaligus sampel jenuh dalam penelitian ini. Adapun lokasi penelitian bertempat di Jl. R. A. Kartini No. 280, Sukorame, Gresik. Wawancara, observasi dan kuesioner dipakai sebagai teknik untuk pengumpul data pada penelitian ini. Sedangkan dalam pengambilan kuesioner pada penelitian ini, skala pengukurannya menggunakan skala likert 1-5. Adapun versi 3.0 dari Partial Least Square (PLS) merupakan software yang dipergunakan untuk penelitian ini, sedangkan SEM (Structural Equation Modelling) sebagai jenis penelitian datanya.

\section{HASIL DAN PEMBAHASAN}

Dilihat berdasarkan pada jenis kelamin, rentang usia, pendidikan terakhir, masa kerja, dan status responden pada penelitian ini memiliki karakteristik sebagai berikut:

\section{Tabel 1 \\ KARAKTERISTIK RESPONDEN}

\begin{tabular}{lcc}
\hline \multicolumn{1}{c}{ Karakteristik Responden } & Frekuensi & Presentase \\
\hline Jenis Kelamin & & \\
a. Laki-laki & 31 & $62 \%$ \\
b. Perempuan & 19 & $38 \%$ \\
Rentang Usia & & \\
a. $<30$ th & 1 & $2 \%$ \\
b. $30-40$ th & 15 & $30 \%$ \\
c. $41-50$ & 22 & $44 \%$ \\
d. $>50$ th & 12 & $24 \%$ \\
Pendidikan terakhir & & \\
a. SLTA & 23 & $46 \%$ \\
b. D3 & 9 & $18 \%$ \\
c. S1 & 12 & $24 \%$ \\
d. Lain-lain & 6 & $12 \%$ \\
Masa Kerja & & \\
a. > 5-10 th & 13 & $26 \%$ \\
b. > 10 -20 th & 19 & $38 \%$ \\
c. > 20 th & 18 & $36 \%$ \\
Status & & \\
a. Belum Menikah & 2 & $4 \%$ \\
b. Menikah & 48 & $96 \%$ \\
\hline Sum : Output SPS, 2019 \\
\hline
\end{tabular}

Sumber : Output SPSS, 2019

\section{Hasil Analisis Statistik Inferensial}

Pemenuhan nilai sebuah convergent validity untuk dinyatakan valid ketika sebuah indikator sudah bernilai lebih dari 0,50 untuk outer loadingnya. Berdasarkan nilai outer loading dari penelitian ini seluruh indikatornya menunjukkan nilai $>0,50$, maka indikator tersebut dinyatakan valid. Sedangkan konstruk akan dinyatakan reliable ketika composite reliability di atas 0,70 nilainya. Composite reliability dalam penelitian ini masing-masing bernilai 0,868 untuk variabel kepuasan kerja, bernilai 0,887 untuk komitmen afektif, dan bernilai 0,842 untuk variabel kinerja karyawan. Sehingga dianggap valid dan reliabel penggunaan variabel dalam penelitian ini. 


\section{Analisis R-Square (Inner Model)}

Pada penelitian ini nilai dari $R$-Square dimanfaatkan dalam mengetahui pengaruh antar variabel. Ketika $R$-Square nilainya di bawah $0,19-0,33$ dinyatakan bernilai rendah, ketika $R$-Square bernilai 0,33-0,67 dinyatakan bernilai sedang, dan ketika nilai $R$-Square bernilai 0,67 ke atas dinyatakan bernilai kuat (Ghozali, 2016).

Tabel 2

$R-S Q U A R E$

\begin{tabular}{lc}
\hline \multicolumn{1}{c}{ Variabel } & R-Square \\
\hline Kepuasan Kerja $(\mathrm{X})$ & - \\
Komitmen Afektif $(\mathrm{Z})$ & 0,073 \\
Kinerja Karyawan $(\mathrm{Y})$ & 0,463 \\
\hline Sumber: Result smartPLS 3.0 &
\end{tabular}

Nilai R-Square yang ditunjukkan pada Tabel 2 di atas sebesar 0,073 untuk model mediasi komitmen afektif terhadap pengaruh kepuasan kerja pada kinerja karyawan. Interprestasi yang dihasilkan dari Tabel 2 yaitu kepuasan kerja dapat memberikan penjelasan pada variabel konstruk komitmen afektif dengan nilai sebasar 7,3\%, sedangkan sisanya senilai $92,7 \%$ tidak dijelaskan dalam penelitian ini. Pada Tabel 2 juga ditunjukkan model mediasi komitmen afektif pada kepuasan kerja yang dipengaruhi kinerja karyawan adalah sebesar 0,463 untuk nilai $R$-Square yang diberikan. Sehingga interprestasi yang dihasilkan yaitu variabel kinerja karyawan dapat dijelaskan senilai 46,3\% oleh variabel konstruk kepuasan kerja sedangkan 53,7\% tidak dijelaskan pada penelitian ini.

\section{Hasil Uji T (Signifikansi)}

Uji signifikansi atau uji $\mathrm{T}$ digunakan dalam penelitian ini agar dapat dimengerti pengaruh antar variabel yang diteliti baik secara signifikan atau tidak. Adapun path coefficients yang dihasilkan adalah sebagai berikut:

Tabel 3

\section{PATH COEFFICIENTS}

\begin{tabular}{|c|c|c|c|c|}
\hline Pengaruh Antar Variabel & $\begin{array}{c}\text { Original } \\
\text { Sampel }\end{array}$ & T Statistics & Keterangan & Kesimpulan \\
\hline Kepuasan Kerja $\longrightarrow$ Kinerja Karyawan & 0,611 & 5,377 & $\begin{array}{l}\geq 1,96 \\
\text { (Signifikan) }\end{array}$ & $\begin{array}{l}\text { Hipotesis } \\
\text { Diterima }\end{array}$ \\
\hline Kepuasan Kerja $\longrightarrow$ Komitmen Afektif & 0,269 & 2,102 & $\begin{array}{l}\geq 1,96 \\
\text { (Signifikan) }\end{array}$ & $\begin{array}{l}\text { Hipotesis } \\
\text { Diterima }\end{array}$ \\
\hline Komitmen Afektif $\longrightarrow$ Kinerja Karyawan & 0,176 & 1,307 & $\begin{array}{l}\leq 1,96 \text { (Tidak } \\
\text { Signifikan) }\end{array}$ & $\begin{array}{l}\text { Hipotesis } \\
\text { Ditolak }\end{array}$ \\
\hline $\begin{array}{l}\text { Kepuasan Kerja } \longrightarrow \text { Komitmen Afektif } \longrightarrow \\
\text { Kinerja Karyawan }\end{array}$ & 0,048 & 0,344 & $\begin{array}{l}\leq 1,96 \text { (Tidak } \\
\text { Signifikan) }\end{array}$ & $\begin{array}{l}\text { Hipotesis } \\
\text { Ditolak }\end{array}$ \\
\hline
\end{tabular}

Sumber: Result smartPLS 3.0

Tabel 3 di atas T-statistik menunjukkan nilai $>1,96$ atau senilai 5,377, maka secara signifikan variabel kepuasan kerja memengaruhi variebel kinerja karyawan. Adapun koefisien yang ditunjukkan pada Tabel 3 bertanda positif dengan nilai 0,611. Hal tersebut tingginya kepuasan kerja berdampak pada tingginya komitmen afektif.

T-statistic bernilai 2,102 pada komitmen afektif yang memengaruhi kepuasan kerja atau $>1,96$. Jadi, secara signifikan variabel kepuasan kerja memengaruhi variabel komitmen afektif. Sedangkan 0,269 untuk nilai koefisien parameter pada Tabel 3 bernilai positif yang berarti tingginya kepuasan kerja akan membuat komitmen afektif juga tinggi. 
Lia Widya Ningsih. Pengaruh Kepuasan Kerja terhadap Kinerja Karyawan melalui Komitmen Afektif pada PT Cipta Nirmala

T-statistic bernilai 0,176 atau $<1,96$ untuk kinerja karyawan yang dipengaruhi komitmen afektif ditunjukkan pada Tabel 3. Jadi, komitmen afektif tidak memberikan pengaruh pada variabel kinerja karyawan. Hingga ketika komitmen afektif bernilai tinggi ataupun rendah tidak memberikan pengaruh pada kinerja karyawan.

Koefisien senilai 0,48 ditunjukkan pada Tabel 3 untuk pengaruh tidak langsung pada mediasi komitmen afektif pada pengaruh kepuasan kerja terhadap kinerja atau bernilai lebih kecil dari pengaruh langsung yang bernilai 0,661 untuk kinerja karyawan yang dipengaruhi kepuasan kerja. Jadi, secara langsung kinerja karyawan dipengaruhi oleh kepuasan kerja dan tidak ada peran mediasi komitmen afektif untuk kinerja karyawan yang dipengaruhi kepuasan kerja.

\section{Pengaruh Kepuasan Kerja terhadap Kinerja Karyawan PT Cipta Nirmala}

H1 diterima pada penelitian ini yaitu "Kepuasan kerja berpengaruh signifikan positif terhadap kinerja karyawan pada PT Cipta Nirmala". Novita et al., (2016) mendukung penelitian ini dengan hasil dari penelitiannya yang menunjukkan secara signifikan positif kepuasan kerja memberikan pengaruh pada kinerja karyawan. Hingga tingginya peningkatan sebuah kepuasan kerja berdampak pada peningkatan pada tingginya kinerja karyawan. Adapun penelitian yang memiliki hasil sama yaitu penelitian yang dilakukan Armanu \& Mandayanti (2012), Indrawati (2013), Manuel \& Rahyuda (2015) dan Inuwa (2016).

Berdasarkan hasil wawancara di lapangan karyawan menyatakan merasa puas dengan pekerjaan mereka sehingga merasa bertanggung jawab penuh atas kinerja yang mereka hasilkan. Salah satu hal membuat mereka merasa puas adalah diberikannya kesempatan promosi ketika mereka mampu memenuhi target penilain kerja selama beberapa periode. Hal tersebut mampu memotivasi mereka dalam meningkatkan kinerja karena merasa apa yang telah mereka usahakan sangat dihargai perusahaan. Adapun mengenai kepuasan gaji, bonus, dan rekan kerja sejauh ini tidak terdapat masalah. Gaji minimal yang diberikan sudah sesuai UMK Kabupaten Gresik yaitu sebesar Rp 3.867.847,40, dan dapat bertambah sesuai tingkat pendidikan dan prestasi karyawan. Bonus yang diberikan juga dinilai cukup yaitu Rp 50.000,00 pada jam pertama dan kedua, sedangkan untuk jam berikutnya diberikan penambahan lebih dari itu. Hubungan antar karyawan juga terjalin baik, bahkan setahun sekali beberapa bagian mengadakan liburan bersama.

Meskipun mereka merasa puas dengan pekerjaannya, namun salah satu hal yang kurang memuaskan adalah mengenai pengawasan. Beberapa karyawan merasa kurang nyaman ketika bekerja harus diawasi karena kurang leluasa dalam menyelesaikan pekerjaannya. Selain itu sikap atasan yang kadang kurang ramah membuat mereka merasa sedikit terganggu. Sehingga kinerja yang mereka lakukan dirasa kurang maksimal.

\section{Pengaruh Kepuasan Kerja terhadap Komitmen Afektif pada PT Cipta Nirmala}

$\mathrm{H} 2$ dalam penelitian ini dinyatakan diterima yaitu "Kepuasan kerja berpengaruh signifikan positif terhadap komitmen afektif pada PT Cipta Nirmala". Hasil ini didukung oleh penelitian Dinc dan Plakalovic (2016), yang memberikan pernyataan bahwa kepuasan kerja secara positif dan signifikan memberikan pengaruh pada komitmen afektif. Sehingga dapat ditunjukkan pada penelitian ini bahwa meningkatnya komitmen afektif terjadi ketika terjadi peningkatan kepuasan kerja. Kemudian menurut Israel et al., (2015) dan Hanifah (2016) juga memiliki hasil yang sejalan dengan penelitian ini.

Hasil wawancara pada karyawan di lapangan menunjukkan bahwa perasaan akan kepuasan kerja pada karyawan membuat mereka tidak tertarik untuk ke luar dari pekerjaan mereka saat ini. Jika dirata-rata memang 74\% karyawan telah bekerja lebih dari 10 tahun. Mereka ingin terus berkarir dan mengembangkan diri mereka untuk perusahaan sehingga tidak ada keinginan untuk mencari pekerjaan pengganti. Bagi mereka ketika harus mencari pekerjaan yang baru, maka akan butuh penyesuaian lagi dan belum tentu sesuai dengan yang mereka harapkan nantinya. Selain itu dengan dukungan dari rekan kerja, gaji dan bonus yang sesuai dan adanya kesempatan promosi membuat mereka merasa nyaman dengan pekerjaaannnya saat ini. Sehingga rasa ingin keluar dan mencari pekerjaan lain tidak terfikirkan oleh mereka. 


\section{Pengaruh Komitmen Afektif terhadap Kinerja Karyawan pada PT Cipta Nirmala}

H3 pada penelitian ini dinyatakan tertolak dengan pernyataan bahwa "Komitmen afektif berpengaruh terhadap kinerja karyawan pada PT Cipta Nirmala". Jadi, ketika tinggi maupun rendah sebuah komitmen afektif yang ada tidak memengaruhi kinerja karyawan. Penelitian oleh Hanifah (2016) mendukung penelitian ini yang memberikan pernyataan bahwa komitmen afektif tidak memberikan pengaruh pada kinerja karyawan.

Wawancara yang diperoleh dari lapangan menunjukkan bahwa karyawan telah menganggap pekerjaan mereka sebagai tanggungjawab yang perlu diselesaikan, baik mereka karyawan lama atau karyawan baru. Mereka bahkan saling membantu menyelesaikan pekerjaan ketika ada karyawan yang tidak masuk atau ketika pekerjaan mereka telah selesai dan rekan kerjanya belum selesai. Sebagai karyawan mereka meyakini bahwa ketika mereka saling tolong-menolong dan bekerjasama dalam menyelesaikan pekerjaan maka mereka akan lebih berhasil daripada hanya mementingkan kepentingan secara individu.

Meskipun sudah berusaha sebaik mungkin dalam menyelesaikan pekerjaan, hasil wawancara di lapangan menunjukkan bahwa ada beberapa karyawan yang menyebutkan terkadang masih ada keterlambatan dalam penyelesaian pekerjaan. Setelah ditelusuri ternyata salah satu penyebab terlambatnya penyelesaian pekerjaan karena ada perubahan sistem pengolahan data yang perlu berbagai penyesuaian. Selain itu, pemasukan data yang tak terkontrol juga menjadi penyebab lain dalam terlambatnya penyelesaian pekerjaan mereka.

\section{Pengaruh Kepuasan Kerja terhadap Kinerja Karyawan melalui Komitmen Afektif pada PT Cipta Nirmala}

Secara langsung kinerja karyawan dipengaruhi oleh kepuasan kerja dan tidak ada peran mediasi komitmen afektif untuk kinerja karyawan yang dipengaruhi kepuasan kerja. Hasil yang diberikan berdasarkan wawancara dengan di lapangan memberikan informasi yaitu kepuasan kerja karyawan PT Cipta Nirmala lebih memengaruhi kinerja karyawan daripada komitmen afektif karyawan. Mereka berpendapat bahwa seberapa lama mereka bekerja tidak menentukan bagaimana kinerja yang mereka hasilkan karena peningkatan kinerja akan ada ketika mereka merasa puas akan pekerjaan mereka sendiri. Meskipun mereka tidak ingin keluar dari pekerjaan mereka namun terkadang kinerja mereka mengalami penurunan atau kenaikan tertentu ketika dihubungkan dengan kepuasan dalam bekerja.

Penelitian Hanifah (2016) merupakan penelitian yang mendukung penelitian ini, jika dilihat berdasar pada penunjukkan hasil yang diperoleh yaitu kepuasan kerja tidak memberikan pengaruh pada kinerja karyawan dengan dimediasi oleh komitmen afektif. Hingga penarikan kesimpulan dalam penelitian ini H4 ditolak.

\section{KESIMPULAN}

Secara signifikan positif kepuasan kerja pada PT Cipta Nirmala memberikan pengaruh pada kinerja karyawan. Secara signifikan positif kepuasan kerja pada PT Cipta Nirmala memberikan pengaruh pada komitmen afektif. Tidak terdapat pemberian pengaruh komitmen afektif pada PT Cipta Nirmala pada kinerja karyawan. Tidak terdapat mediasi komitmen afektif Pada PT Cipta Nirmala untuk pengaruh kepuasan kerja pada kinerja karyawan.

Atasan diharapkan untuk lebih bersikap ramah kepada bawahannya. Sikap ramah tersebut diharapkan mampu membuat karyawan lebih nyaman dan dapat memaksimalkan kinerjanya. Kemudian, dalam meminimalisir ketidaktepatan waktu karena perubahan sistem, diharapkan karyawan dipersiapkan dengan baik dengan melakukan pelatihan-pelatihan agar karyawan mampu melakukan penyesuaian lebih cepat dengan perubahan sistem yang baru. Sehingga kinerja yang mereka lakukan dapat tepat waktu dan tidak mengalami hambatan. 
Lia Widya Ningsih. Pengaruh Kepuasan Kerja terhadap Kinerja Karyawan melalui Komitmen Afektif pada PT Cipta Nirmala

Penelitian ini memiliki keterbatasan pada sampel yang digunakan yang kurang dari 100 yaitu hanya 50 responden. Sehingga hasil yang didapat belum bisa dikatakan pada subyek penelitian jumlah besar. Sampel yang digunakan hanya karyawan tetap bagian kantor saja dalam penelitian ini, sehingga diharapkan pada penelitian selanjutkan dapat menambahkan karyawan bagian lain pada PT Cipta Nirmala agar tidak hanya diperoleh hasil penelitian dari satu bagian saja. Selain itu berdasarkan hasil wawancara di lapangan menunjukkan terdapat hal lain yang memengaruhi kinerja karyawan yaitu perilaku karyawan yang sukarela dalam membantu karyawan lain atau dapat disebut altruism. Sehingga penelitian selanjutnya dapat memertimbangkan variabel altruism sebagai variabel dependen dalam penelitiannya.

\section{DAFTAR PUSTAKA}

Amstrong, M., \& Baron, A. (2005). Managing Performance; Performance Management in Action (1st ed.). London: Chartered Institut of Personal and Development.

Armanu, F. R., \& Mandayanti, N. (2012). Pengaruh Permberdayaan Psikologis dan Komitmen Afektif Terhadap Kepuasan Kerja dan Kinerja Pegawai (Studi pada Dinas Tata Kota dan Pengawasan Bangunan Kota Mataram). Jurnal Manajemen.

Atmojo, M. (2017). The Influence of Transformational Leadership on Achievement Motivation and Organizational Climate and Employee Performance. International Journal of Academic Research in Business and Social Sciences, 6(12). https://doi.org/10.6007/ijarbss/v6-i12/2522

Boon, O. K., Safa, M. S., \& Arumugam, V. (2006). TQM practices and affective commitment: a case of Malaysian semiconductor packaging organizations. Energy, (10864).

Dharma, A. (2003). Manajemen Supervisi. Jakarta: PT Raja Grafindo Persada.

Dinc, M. S., \& Plakalovic, V. (2016). Impact of Caring Climate, Job Satisfaction, and Affective Commitment on Employees Performance in the Banking Sector of Bosnia and Herzegovina. Eurasian Journal of Business and Economics, 9(18), 1-16. https://doi.org/10.17015/ejbe.2016.018.01

Duha, T. (2016). Perilaku Organisasi (1st ed.). Yogyakarta: Deepublish.

Ezeanyim, Ezinwa, E., Ufoaroh, Ebele, T., \& Ajakpo. (2019). The Impact of Job Satisfaction on Employee Performance in Selected Public Enterprise in Awka, Anambra State. Journal of Management and Business Research: A Administration and Management, 19(7), 11.

George, J. M., \& Jones, G. M. (2007). Understanding and Managing Organizational Behavior (6th ed.). New Jersey: Pearson Prentice Hall.

Ghozali, I. (2015). Aplikasi Analisis Multivariate dengan Program IBM SPSS. Semarang: Badan Penerbit Universitas Diponegoro.

Hanifah, N. (2016). Pengaruh Kepuasan Kerja Terhadap Kinerja Karyawan Melalui Komitmen Afektif ( Studi pada karyawan PT. Petrokopindo Cipta Selaras Gresik ). Jurnal Ilmu Manajemen, 4(3), 1-10.

Hasibuan, M. (2009). Manajemen Sumber Daya Manusia (Edisi Refi). Jakarta: Bumi Aksara.

Indrawati, A. D. (2013). Pengaruh Kepuasan Kerja terhadap Kinerja Karyawan dan Kepuasan Pelanggan pada Rumah Sakit Swasta di Kota Denpasar. Managemen, Strategi Bisnis Dan Kewirausahaan, 7(2), 135-142. 
Inuwa, M. (2016). Job satisfaction and employee performance: An empirical approach. The Millennium University, 1(1), 90-103. https://doi.org/10.1161/STROKEAHA.112.655050

Israel, A. N., Rita, A. A., \& Dele, A. O. (2015). The Effect of Job Satisfaction on Organisational Commitment Among Non-Academic Staff of Tertiary Institutions in Ekiti State. International Journal of Interdisciplinary Research Method, 2(1), 25-39.

Kerisna, I. G., \& Suana, I. W. (2017). Pengaruh Kepuasan Kerja Terhadap Komitmen Organisasi dan Organizational Citizenship Behavior. 6(7), 3962-3990.

Kreitner, R., \& Kinicki, A. (2014). Perilaku Organisasi. Jakarta: Salemba Empat.

Luthans, F. (2006). Perilaku Organisasi. Yogyakarta: Andi.

Mangkunegara, A. P. (2013). Manajemen Sumber Daya Manusia Perusahaan (1st ed.). Bandung: PT Remaja Rosdakarya Offset.

Manuel, G. P. E. B., \& Rahyuda, A. G. (2015). Pengaruh Kepuasan Kerja, Komitmen Afektif, Komitmen Kalkulatif dan Komitmen Normatif Terhadap Turnover Intention Di Ayodya Resort Bali. E-Jurnal Manajemen Unud, 4(8), 2243-2268.

Mello, A. J. (2015). Strategic Human Resource Management (4th ed.). Stamford: Cengage Learning Publisher.

Memari, N., Mahdieh, O., \& Marnani, A. B. (2013). The impact of Organizational Commitment on Employees Job Performance. "A study of Meli bank." Interdisciplinary Journal of Contemporary Research in Business, 5(5), 164-171.

Meyer, J. P., \& Allen, N. J. (1991). A Three-Component Conceptualization of Organizational Commitment. 1(1), 1-3. Retrieved from papers2://publication/uuid/86247CC4-7070-47AB98AE-3D2410A0646F

Meyer, J. P., Stanley, D. J., Herscovitch, L., \& Topolnytsky, L. (2002). Affective, Continuance, and Normative Commitment to the Organization: A Meta-analysis of Antecedents, Correlates, and Consequences. Journal of Vocational Behavior, 61(1), 20-52. https://doi.org/10.1006/jvbe.2001.1842

Mustafa, G., Ilyas, M., \& Rehman, A. (2016). Do the Employees ' Job Satisfaction interferes organizational Culture and Affective Commitment Relationship: Test of ... phd thesis View project. Journal of Applied Environmental and Biological Sciences, 6(5), 125-133.

Novita, Sunuharjo, B. S., \& Ruhana, I. (2016). Pengaruh Kepuasan Kerja dan Komitmen Organisasional Terhadap Kinerja Karyawan (Studi pada PT Telekomunikasi Indonesia, Tbk Witel Jatim Selatan, Malang). Jurnal Administrasi Bisnis (JAB), 34(1), 38-46.

Nurbiyati, T., \& Wibisono, K. (2014). Analisis Pengaruh Komitmen Afektif, Kontinyu Dan Normatif Terhadap Kinerja Dengan Disiplin Kerja Sebagai Variabel Intervening. Kajian Bisnis STIE Widya Wiwaha, 22(1), 21-37. https://doi.org/10.32477/jkb.v22i1.195

Nurnaningsih, S., \& Wahyono. (2017). Pengaruh Komitmen Organisasional Terhadap Kepuasan Kerja Dengan Organizational Citizenship Behavior (OCB) Sebagai Variabel Intervening. 6(2), $365-378$.

Parven, A., \& Awan, A. G. (2018). The Effect of Organizational Justice, Job satisfaction and Trust on Managers on Employee Performance. 4(2), 205-218. https://doi.org/10.1007/978-3-319-71225- 
Lia Widya Ningsih. Pengaruh Kepuasan Kerja terhadap Kinerja Karyawan melalui Komitmen Afektif pada PT Cipta Nirmala

$$
\text { 3_18 }
$$

Perangin-Angin, M. R., Lumbanraja, P., \& Absah, Y. (2020). The Effect of Quality of Work Life and Work Engagement to Employee Performance with Job Satisfaction as an Intervening Variable in PT. Mopoly Raya Medan. International Journal of Research and Review, 7(2), 72-78. https://doi.org/10.18551/rjoas.2018-02.12

Ratnasari, S. L., \& Hartati, Y. (2019). Manajemen Kinerja dalam Organsasi (1st ed.). Pasuruan: Qiara Media.

Rini, D. P., Rusdarti, \& Suparjo. (2013). Pengaruh Komitmen Organisasi, Kepuasan Kerja dan Budaya Organisasi Terhadap Organizational Citizenship Behavior (OCB) (Studi pada PT Plasa Simpanglima Semarang). 1(1), 69-88.

Riyadi, S. (2019). the Influence of Job Satisfaction, Work Environment, Individual Characteristics and Compensation Toward Job Stress and Employee Performance. International Review of Management and Marketing, 9(3), 93-99. https://doi.org/10.32479/irmm.6920

Robbins, S. P. (2001). Organizational Behavior (9th ed.). New Jersey: Prentice Hall.

Robbins, S. P. (2012). Perilaku Organisasi. Jakarta: Salemba Empat.

Robbins, S. P., \& Timothy, A. J. (2015). Perilaku Organisasi. Jakarta: Salemba Empat.

Roberts, J. A., \& David, M. E. (2020). Boss phubbing, trust, job satisfaction and employee performance. Personality and Individual Differences, 155(October), 109702. https://doi.org/10.1016/j.paid.2019.109702

Sani, A. (2013). Role of Procedural Justice, Organizational Commitment and Job Satisfaction on job Performance: The Mediating Effects of Organizational Citizenship Behavior. International Journal of Business and Management, 8(15), 57-67. https://doi.org/10.5539/ijbm.v8n15p57

Siengthai, S., \& Pila-Ngarm, P. (2016). The interaction effect of job redesign and job satisfaction on employee performance. Evidence-Based HRM, 4(2), 162-180. https://doi.org/10.1108/EBHRM-01-2015-0001

Simamora, H. (2006). Manajemen Sumber Daya Manusia (3rd ed.). Yogyakarta: STIE YKPN.

Squires, J. E., Hoben, M., Linklater, S., Carleton, H. L., Graham, N., \& Estabrooks, C. A. (2015). Job Satisfaction among Care Aides in Residential Long-Term Care: A Systematic Review of Contributing Factors, Both Individual and Organizational. Nursing Research and Practice, 2015, 1-24. https://doi.org/10.1155/2015/157924

Suparyadi. (2015). Manajemen Sumber Daya Manusia, Menciptakan Keunggulan Bersaing Berbasis Kompetensi SDM (1st ed.). Yogyakarta: Andi. 